\title{
Efektivitas Model Pembelajaran Group Investigation (GI) dan Teams Games Tournament (TGT) Ditinjau dari Kemampuan Berpikir Kritis Matematika
}

\author{
Intan Diyah Retno Palupi ${ }^{1}$, Theresia Sri Rahayu ${ }^{2}$ \\ 12 Pendidikan Guru Sekolah Dasar, Universitas Kristen Satya Wacana, Salatiga, Indonesia \\ e-mail: idrp08@gmail.com, theresia.rahayu@uksw.edu
}

\begin{abstract}
Abstrak
Kemampuan berpikir kritis matematika sangat penting dikembangkan, untuk itu diperlukan adanya proses pembelajaran matematika yang banyak melibatkan siswa secara aktif khususnya dalam proses pembelajaran di kelas. Penelitian ini bertujuan untuk mengetahui Keefektivitas model pembelajaran Group Investigatin (GI) dan Teams Games Tournament (TGT) ditinjau dari kemampuan berpikir kritis Matematika. Penelitian yang digunakan adalah kajian meta-analisis, dengan mengumpulkan beberapa artikel serta jurnal yang relevan. Penelitian ini menggunakan beberapa Uji Prasayarat. Untuk menentukan Uji rata-rata penelitian ini menggunakan Uji Ancova untuk mengetahui perbedaan pada model pembelajaran, kemudian dihitung dengan teknik Effect Size berbantuan SPSS 24.00 for Windows. Hasil analisis data diperoleh bahwa Teams Games Tournament lebih efektif dalam meningkatkan kemampuan berpikir kritis Matematika dibandingkan Group Investigation. Hal tersebut dapat dilihat dari hasil data dengan nilai signifikasi > 0,05, dalam Uji Ancova mendapatkan hasil bahwa nilai posttest model pembelajaran Group Investigation yakni 76,3000 dan 82,2000 untuk model pembelajaran Teams Games Tournament. Kemudian, pada $F_{\text {hitung }}$ diperoleh nilai 10,751 dan untuk $F_{\text {tabel }}$ diperoleh hasil 3,59, maka $F_{\text {hitung }}>F_{\text {tabel }}$ dengan nilai 10,751 > 3,59 dan signifikasinya 0,004 <0,05. Untuk Uji Effect Size diperoleh hasil pada Partial Eta Squared yakni 0,297 dengan nilai Siginifikansi 0,004. Maka dapat dinyatakan dari hasil tersebut, bahwa terdapat perbedaan yang signifikan antara model Group Investigation dan model Teams Games Tournament ditinjau dari kemampuan berpikir kritis pada pembelajaran Matematika siswa Sekolah Dasar.
\end{abstract}

Kata Kunci: GI, TGT, Berpikir Kritis, Meta-analisis

\begin{abstract}
The ability to think critically in mathematics is very important to be developed, for that we need a mathematics learning process that involves a lot of students actively, especially in the learning process in the classroom. This aim of this study is to determine the effectiveness of the Group Investigatin (GI) and Teams Games Tournament (TGT) learning model in terms of mathematics critical thinking skills. The research used is a meta-analysis study, by collecting a number of articles and relevant journals. This study uses several pre-requisite tests. To determine the average test of this study using the Ancova test to determine the differences in the model of learning, then it is calculated using the Effect Size technique assisted by SPSS 24.00 for Windows. The results of data analysis show that the Teams Games Tournament is more effective in increasing critical thinking skills in Mathematics than in Group Investigation. This can be seen from the results of the data with a significance score $>0,05$, in the Ancova test, the results show that the posttest score of the Group Investigation learning model are 76.3000 and 82.2000 for the Teams Games Tournament learning model. Then, for Fcount the score is 10,751 and for Ftable the result is 3,59, so that Fcount > Ftable with a score of 10,751 $>3,59$ and the significance is 0,004 0,05. For the Effect Size test, obtained results on Partial Eta Squared is 0,297 with a significance score of 0,004. Therefore, it can be stated from these results, that there is a significant difference between the Group Investigation model and the Teams Games Tournament model in terms of critical thinking skills in Mathematics learning of elementary school students.
\end{abstract}

Keywords: GI, TGT, Critical Thinking, Meta-analysis 


\section{Pendahuluan}

Pendidikan adalah suatu tempat yang didalamnya terdiri atas peserta didik dan pendidik, yang melakukan suatu proses pembelajaran (Aprilia, 2018; Irawan, 2016; Sugiyanto et al., 2015). Dalam dunia pendidikan pembelajaran termasuk proses interaksi antar siswa dengan pendidik yang memiliki hubungan timbal balik. Suatu proses pembelajaran akan berlangsung jika didalamnya terdapat peran antar guru dengan peserta didik, peserta didik dengan guru, sumber belajar, serta lingkungan belajar. Proses komunikasi dua arah ini, merupakan kegiatan yang secara sengaja disusun atau sudah terprogram yang memiliki tujuan untuk menciptakan peserta didik belajar aktif, inovatif, dan bermakna. Pemerintah mengupayakan dalam meningkatkan mutu pendidikan sekolah yakni memperbaiki proses belajar mengajar yang berkualitas.

Penggunaan model dalam proses pembelajaran sangat berpengaruh tinggi pada tingkat keterampilan maupun kemampuan berpikir kritis siswa (Ardianingsih et al., 2017; Indriani, 2015; Machali, 2014). Seperti dalam Model Group Investigation (Gl) dan Teams Games Tournament (TGT) ini, perlunya dilakukan penelitian dengan teknik meta-analisis agar mengetahui perbedaan hasil kemampuan berpikir kritis siswa. Akan tetapi, dalam penggunaan dua model tersebut masih muncul keragu-raguan model pembelajaran mana yang lebih efektif dalam meningkatkan kemampuan berpikir kritis siswa untuk di ujicobakan mengenai efektifitas model pembelajaran. Model Group Investigation (GI) dan Teams Games Tournament (TGT), ditinjau dari kemampuan beripikir kritis siswa SD yang memiliki daya tarik peneliti untuk diteliti lebih lanjut berdasarkan kajian dari penelitian-penelitian sebelumnya. Penggunaan metode saintifik untuk menggabungkan hasil kuantitatif beberapa jurnal penelitian untuk menghasilkan rangkuman atas pengetahuan empiris pada topik tertentu merupakan teknik meta-analisis. Teknik ini sangat penting dilakukan untuk mengoreksi kesalahan dan bias dalam sebuah penelitian. Dengan menggunakan beberapa sampel dari penelitian sebelumnya atau terdahulu dengan variabel sejenis dapat memperoleh informasi dan dapat dianalisis.

Dalam memenuhi perkembangan zaman dan abad 21, dari pengamatan lapangan yang dilakukan penulis K13 ini peran guru mampu menciptakan suasana kelas yang menggunakan konsep PAIKEM GEMBROT (Pembelajaran Aktif, Inovatif, Kreatif, Efektif, Gembira dan Berbobot) dan bermakna. Memiliki pengetahuan dan keterampilan saat kegiatan belajar mengajar didalam kelas, seorang guru yang professional juga harus dituntut untuk memiliki kreatifitas. Dalam pelaksanaan proses pembelajaran pada Sekolah Dasar/Madrasah Ibtidaiyah (SD/MI) terdapat mata pelajaran yang berdiri sendiri seperti Pendidikan Jasmani Olahraga dan Kesehatan (PJOK) serta Matematika untuk kelas tinggi yaitu IV, V dan VI yang dilakukan dengan pendekatan pembelajaran tematik-terpadu. Ilmu uviversal seperti mata pelajaran Matematika didalamnya terdapat konsep abstrak serta gagasan yang berkaitan erat dengan kehidupan sehari-hari manusia. Dalam dunia teknologi dan sains perkembangan ilmu matematika berbanding lurus dengan perkembangan di era digital ini. Maka dari itu, Matematika berperan penting dalam kehidupan manusia bahkan bisa dibilang hidup berdampingan dengan manusia, karena matematika bersifat realistik yaitu ilmu yang hidup berdampingan dengan manusia sehari-hari. Tujuan pembelajaran Matematika yaitu : (a) memahami konsep Matematika, mendeskripsikan bagaimana keterkaitan antar konsep Matematika dan menerapkan konsep atau logaritma secara efisien, luwes, akurat, dan tepat dalam memecahkan masalah; (b) menalar pola sifat dari Matematika, mengembangkan atau memanipulasi Matematika dalam menyusun argument, merumuskan bukti, atau mendeskripsikan argument dan pernyataan Matematika; (c) memecahkan masalah Matematika yang meliputi kemampuan memahami masalah, menyusun model penyelesaian Matematika, menyelesaikan model Matematika, dan member solusi yang tepat; (d) mengkomunikasikan argument atau gagasan dengan diagram, tabel, simbol, atau media lainnya agar dapat memperjelas permasalahan atau keadaan (Awalia et al., 2019; Gazali \& Atsnan, 2017; Rizta \& Antari, 2018).

Dari uraian tersebut dapat disimpulkan bahwa dalam menyelesaikan atau memecahkan masalah Matematika, strategi sangat penting untuk digunakan karena dapat mempermudah peserta didik dalam mengembangkan serta meningkatkan keterampilan berpikir kritis, logis, serta cermat dalam menyelesaikan permasalahan pada pelajaran Matematika. Siswa dapat dikatakan beripikir kritis apabila mampu mengidentifikasi suatu masalah, membuat keputusan, melakukan evaluasi, dan membangun asumsi sehingga muncul suatu strategi untuk pemecahan masalah. Kemampuan berpikir kritis siswa dapat ditingkatkan dengan menerapkan pembelajaran yang berpusat pada siswa. Landasan keterampilan dalam bepikir kritis seperti 
yang dikemukakan oleh (Herzon et al., 2018; Putri et al., 2020; Suriasa, 2018) yakni: (1) memahami permasalahan yang ditemukan; (2) menemukan beberapa cara untuk memecahkan masalah yang ditemukan; (3) mengumpulkan dan menyusun informasi yang diperlukan dalam pemecahan masalah; (4) menganalisis data yang telah diperoleh dari berbagai sumber; (5) memilih fakta yang paling tepat dan mengevaluasi pertanyaan-pertanyaan; (6) menemukan adanya hubungan yang logis antar masalah yang timbul; (7) mengerucutkan kesamaan menjadi suatu kesimpulan; (8) menguji kesimpulan yang dikerucutkan dari persamaan-persamaan; dan (9) membuat penilaian dari kualitas tertentu dalam kehidupan sehari-hari.

Dapat disimpulkan bahwa berpikir kritis adalah sebuah proses sistematis yang memungkinkan siswa untuk merumuskan dan mengevaluasi keyakinan dan pendapat mereka sendiri. Jika siswa terbiasa memilih dan berusaha mengevaluasi informasi yang telah diperoleh, maka meraka akan telatih untuk memecahkan masalah, aktif, berpikir kritis, kreatif, sistematis, dan logis. Sejalan dengan pendapat (Herzon et al., 2018; Putri et al., 2020; Syarifah \& Sumardi, 2015) bahwa berpikir kritis merupakan salah satu kompetensi masa depan yang harus dimiliki oleh siswa.

Adapun indikator-indikator kemampuan berpikir kritis menurut (llham \& Hardiyanti, 2020; Suriasa, 2018; Trimawati et al., 2020) mengidentifikasi indikator atau perilaku yang sistematis dalam berpikir kritis, diataranya yakni : 1) Keterampilan Menganalisis, keterampilan menganalisis merupakan suatu keterampilan menguraikan sebuah struktur ke dalam komponen-komponen agar mengetahui pengorganisasian struktur tersebut. Tujuannya adalah memahami sebuah konsep global dengan cara menguraikan atau merinci globalitas tersebut ke dalam bagian-bagian yang lebih rinci dan terperinci. Pertanyaan analisis, menghendaki agar peserta didik mengidentifikasi langkah-langkah logis yang digunakan dalam proses berpikir hingga sampai kesimpulan. 2) Keterampilan Mensitesis, keterampilan yang berlawanan dengan keterampilan menganalisis. Keterampilan mensintesis merupakan keterampilan menggabungkan bagian-bagian menjadi sebuah bentukan atau susunan yang baru. 3) Keterampilan Mengenal dan Memecahkan Masalah, keterampilan ini menuntut peserta didik untuk memahami masalah dengan kritis sehingga setelah memahami masalah, siswa mampu menangkap beberapa pokok pikiran. Peserta didik mampu mengolah sebuah konsep, dengan tujuan agar peserta didik mampu memahami dan menerapkan konsep - konsep kedalam permasalahan atau ruang lingkup baru. 4) Keterampilan menyimpulkan, keterampilan ini berupa kegiatan akal pikiran peserta didik berdasarkan pengertian atau pengetahuan (kebenaran) yang dimilikinya, untuk mencapai pengetahuan (kebenaran) yang baru. Dan 5) Keterampilan Mengevaluasi atau Menilai, keterampilan ini menuntut pemikiran yang matang dalam menentukan sesuatu dengan berbagai criteria. Keterampilan menilai menghendaki peserta didik agar memberikan penilaian tentang nilai yang diukur dengan menggunakan standar tertentu.

Dari pendapat tersebut dapat disimpulkan terdapat indikitor-indikator kemampuan berpikir kritis untuk mengidentifikasi perilaku yang sistematis pada peserta didik, yakni keterampilan menganalisis, keterampilan mensitesis, keterampilan mengenal dan memecahkan masalah, keterampilan dalam menyimpulkan, dan keterampilan mengevaluasi atau menilai. Menurut (Hasnan et al., 2020; D. Indriyani et al., 2019; Yanwar \& Fadila, 2019), tujuan berpikir kritis ialah untuk menguji suatu pendapat atau ide, termasuk didalamnya melakukan pertimbangan atau pemikiran yang didasarkan pada pendapat yang diajukan. Pertimbanganpertimbangan tersebut biasanya didukung oleh kriteria yang dapat dipertanggungjawabkan. Tujuan berpikir kritis ini dapat membantu siswa membuat kesimpulan dengan mempertimbangkan data dan fakta yang terjadi dilapangan. Adapun aspek yang diukur dalam kemampuan berpikir kritis yaitu dominan kognitif pada jenjang menganalisis (C4) dan mengevaluasi (C5).

Pentingnya pengembangan kemampuan berpikir kritis matematika siswa sejak dini khususnya sejak Sekolah Dasar, maka mutlak diperlukan adanya proses pembelajaran matematika yang banyak melibatkan siswa secara aktif khususnya dalam proses pembelajaran di kelas. Keberhasilan pembelajaran yang dilakukan ditentukan oleh proses pembelajaran yang diterapkan (Dewi et al., 2019; Kristiyanto, 2020; Marudut et al., 2020). Penelitian ini didukung oleh beberapa penelitia sebelumnya yang relevan dengan penelitian ini seperti: (1) penelitian yang dilaksanakan oleh (Wicaksono et al., 2017), yang memperoleh hasil bahwa model pembelajaran group investigation dan think pair share terbukti berpengaruh terhadap kemampuan berpikir kritis siswa; (2) penelitian yang dilaksanakan oleh (Cahyadi, 2016), yang memperoleh hasil bahwa penerapan model TGT terbukti berpengaruh terhadap meningkatkan penguasaan kompetensi pengetahuan IPA siswa; (3) penelitian yang dilaksanakan oleh (Miatun 
\& Khusna, 2020), yang memperoleh hasil bahwa peningkatan kemampuan berpikir kritis matematis siswa dipengaruhi berdasarkan disposisi matematis.

\section{Metode}

Pada jenis penelitian ini ialah menggunakan penelitian meta analisis. Meta analisis adalah analisis kuantitatif dengan mengumpulkan sejumlah data serta menerapkan metode statistik untuk menggabungkan hasil kuantitatif atau data dari kumpulan informasi untuk sampel yang besar dari beberapa penelitian sebelumnya yang bertujuan untuk menghasilkan ringkasan pada penelitian sejenis atau topik tertentu. Meta analisis ini bersifat subjektif yang tidak fokus pada kesimpulan saja, akan tetapi berfokus pada data, sejenis dengan melakukan identifikasi atau analisis pada variabel, ukuran sampel, serta besar efek yang didapatkan.

Teknik pada meta analisis ini yakni meringkas hasil penelitian pada penelitian sebelumnya secara kuantitatif yaitu dengan cara menilai effect size. Teknik ini dapat digunakan dengan cara mencari perbedaan rata-rata antar kelas eksperimen dengan kelas kontrol, yang selanjutnya dibagi dengan standart deviasi kelas kontrol. Dimensi effect size merupakan gabungan dari penelitian meta analisis dalam artikel atau jurnal yang sebelumnya.

Sedangkan untuk desain penelitian ini dengan cara Pre-eksperimental dengan tipe One-group Pretest Posttest Design. Dalam pengumpulan data, instrument yang digunakan yaitu tes berupa uraian dan dokumentasi. Analisis data berupa data kuantitatif yaitu perhitungan ratarata nilai Pretest dan Posttest, uji normalitas, uji homogenitas, uji linearitas, uji ancova, dan uji Effect Size. Dengan menggunakan tenik pretest dan posttest model pembelajaran yang digunakan peneliti dapat mengetahui hasil analisis data dengan melalui beberapa uji berbantuan SPSS 24.00 for windows. Uji Effect Size yang digabungkan dalam meta analisis sama dengan yang dilaporkan dalam artikel yang digabungkan. Desain ini memiliki pengaruh dalam peningkatan berpikir kritis Matematika dengan dipadukan dengan kedua model pembelajaran.

\section{Hasil dan Pembahasan}

Hasil

Adapun hasil analisis data untuk distribusi kinerja model pembelajaran Group Investigation dan Teams Games Tournament. berikut ini distribusi kinerja model pembelajaran dapat dilihat pada Tabel 1.

Tabel 1. Distribusi Kinerja Model Pembelajaran

\begin{tabular}{ccc}
\hline Hasil Analisis & Kelas Group Investigation & $\begin{array}{c}\text { Kelas Teams Games } \\
\text { Tournament }\end{array}$ \\
\hline Mean & 18,60 & 20,00 \\
Median & 19,50 & 20,00 \\
Modus & 19 & 11 \\
Standar Deviasi & 7,834 & 8,055 \\
Varian & 61,378 & 64,889 \\
Minimum & 7 & 10 \\
Maximum & 32 & 34 \\
Rentangan & 25 & 24 \\
\hline
\end{tabular}

\section{Hasil Uji Prasyarat Analisis}

Sebelum melakukan rangkaian Uji Ancova serta Effect Size maka harus dilakukan beberapa uji prasyarat. Pertama, uji normalitas dilakukan untuk membuktikan bahwa kedua model pembelajaran berdistribusi normal terhadap kemampuan berpikir kritis. Adapun hasil perhitungan dari uji normalitas pretest dan posttest dapat disajikan pada Tabel 2.

Tabel 2. Uji Normalitas Pretest dan Posstest Model Pembelajaran Group Investigation dan Teams Games Tournament 
TSCJ, Vol 4 No 1, Tahun 2021

p-ISSN : 2615-4692 e-ISSN : 2615-6105

\begin{tabular}{llrrrrrr}
\hline & Posttest & Statistic & df & \multicolumn{1}{c}{ Sig. } & Statistic & df & Sig. \\
\hline Kemampuan Berpikir & Pretest GI & .185 & 10 & $.200^{*}$ & .933 & 10 & .483 \\
Kritis & & .126 & 10 & $.200^{*}$ & .952 & 10 & .694 \\
& Posttest GI & .177 & 10 & $.200^{*}$ & .948 & 10 & .647 \\
& Pretest TGT & .159 & 10 & $.200^{*}$ & .896 & 10 & .196 \\
\hline
\end{tabular}

Berdasarkan perhitungan dengan menggunakan SPSS 24.00 for Windows, diperoleh nilai atau hasil Pretest dan Posttest yang menghasilkan nilai Signifikan $>0,05$ maka data tersebut normal, akan tetapi jika nilai Signifikansi $<0,05$ maka data tersebut tidak normal. Hasil analisis pada uji normalitas pada skor Pretest model pembelajaran Group Investigation tingkat signifikan 0,483 $>0,05$. Skor Posttest pada model pembelajaran Group Investigation tingkat signifikansi yakni 0,694 >0,05. Sedangkan skor Pretest pada model pembelajaran Teams Games Tournament tingkat signifikansi yakni $0,647>0,05$. Skor Posttest pada model pembelajaran Teams Games Tournament dengan tingkat signifikansi yakni 0,196 >0,05. Dapat disimpulkan bahwa hasil dari Pretest dan Posttest dari kedua model pembelajaran menghasilkan nilai yang Signifikan > 0,05 yang berdistribusi normal. Setelah melakukan uji prasyarat yang pertama yaitu uji normalitas, selanjutnya dilakukan uji prasyarat yang kedua yaitu uji homogenitas dapat dilihat pada Tabel 3.

Tabel 3. Tabel 4.11 Uji Homogenitas Pretest dan Posttest Group Investigation dan Teams Games Tournament

\begin{tabular}{lcccccr}
\hline & Levene Statistic & df1 & df2 & \multicolumn{2}{c}{ Sig. } \\
\hline Pretest & .411 & 1 & 18 & .529 \\
\hline Posttest & .446 & 1 & 18 & .513 \\
\hline
\end{tabular}

Berdasarkan tabel di atas, hasil nilai dari pretest dan posttest dari model pembelajaran Group Investigation serta Teams Games Tournament memiliki variasi homogen yang sama. Nilai atau skor signifikansi yang dihasilkan adalah $0,529>0,05$ untuk nilai pretest model pembelajaran Group Investigation dan Teams Games Tournament. Sedangkan posttest model pembelajaran Group Investigation dan Teams Games Tournament, nilai atau skor signifikansi adalah $0,513>0,05$. Selanjutnya dilakukan uji prasayarat yang ketiga yaitu Uji Linearitas dapat dilihat pada Tabel 4

Tabel 4. Uji Linearitas Pretest dan Posttest model pembelajaran Group Investigation

\begin{tabular}{|c|c|c|c|c|c|c|c|}
\hline & & & $\begin{array}{l}\text { Sum of } \\
\text { Squares }\end{array}$ & df & $\begin{array}{l}\text { Mean } \\
\text { Square }\end{array}$ & $\mathbf{F}$ & Sig. \\
\hline \multirow{3}{*}{$\begin{array}{l}\text { Posttest * } \\
\text { Pretest }\end{array}$} & \multirow{2}{*}{$\begin{array}{l}\text { Between } \\
\text { Groups }\end{array}$} & (Combined) & 406.100 & 8 & 50.763 & 1.586 & .550 \\
\hline & & $\begin{array}{l}\text { Linearity } \\
\text { Deviation from } \\
\text { Linearity }\end{array}$ & $\begin{array}{r}32.643 \\
373.457\end{array}$ & $\begin{array}{l}1 \\
7\end{array}$ & $\begin{array}{l}32.643 \\
53.351\end{array}$ & $\begin{array}{l}1.020 \\
1.667\end{array}$ & $\begin{array}{l}.497 \\
.536\end{array}$ \\
\hline & \multicolumn{2}{|c|}{$\begin{array}{l}\text { Within Groups } \\
\text { Total }\end{array}$} & $\begin{array}{r}32.000 \\
438.100 \\
\end{array}$ & $\begin{array}{l}1 \\
9 \\
\end{array}$ & 32.000 & & \\
\hline
\end{tabular}

Dari hasil perhitungan tabel di atas menunjukkan Uji Linearitas Pretest dan Posttest model pembelajaran Group Investigation terdapat hubungan yang linear, dengan nilai Sig. $0,536>0,05$. Uji linearitas pretest dan posttest model pembelajaran teams' games tournament dapat dilihat pada Tabel 5

Tabel 5. Uji Linearitas Pretest dan Posttest model pembelajaran Teams Games Tournament

\begin{tabular}{llrrrrrr}
\hline & & & $\begin{array}{c}\text { Sum of } \\
\text { Squares }\end{array}$ & \multicolumn{1}{c}{$\begin{array}{c}\text { Mean } \\
\text { Square }\end{array}$} & \multicolumn{1}{c}{ F } & \multicolumn{1}{c}{ Sig. } \\
\hline $\begin{array}{llllll}\text { Posttest } \\
\text { Pretest }\end{array}$ & $\begin{array}{l}\text { Between } \\
\text { Groups }\end{array}$ & (Combined) & 245.600 & 8 & 30.700 & 1.706 & .534 \\
\cline { 3 - 9 } & & Linearity & .520 & 1 & .520 & .029 & .893 \\
\hline
\end{tabular}




\begin{tabular}{lrrrrr}
\hline $\begin{array}{c}\text { Deviation from } \\
\text { Linearity }\end{array}$ & 245.080 & 7 & 35.011 & 1.945 & .503 \\
\cline { 2 - 6 } & 18.000 & 1 & 18.000 & & \\
\cline { 2 - 6 } & Within Groups & 263.600 & 9 & & \\
\hline
\end{tabular}

Dapat dilihat dari tabel di atas menunjukkan hubungan yang linear pada Pretest dan Posttest model pembelajaran Teams Games Tournament dengan nilai yang Sig. 0,503 > 0,05. Dapat disimpulkan bahwa Uji Linearitas Pretest dan Posttest model pembelajaran Group Investigation dan Teams Games Tournament menunjukkan hubungan linear. Setelah melakukan uji prasyarat yang ketiga Uji Linearitas, maka selanjutnya Uji Ancova dapat dilihat pada Tabel 6.

Tabel 6. Hasil Analisis Data menggunakan Uji Ancova

\begin{tabular}{lrrr}
\hline Dependent Variable: & Posttest & & \\
\hline Kelas & Mean & Std. Deviation & N \\
\hline Kelas Gl & 76.3000 & 8.49902 & 10 \\
Kelas TGT & 82.2000 & 5.41192 & 10 \\
Total & 79.2500 & 7.56637 & 20 \\
\hline
\end{tabular}

Dari hasil analisis data diatas Uji Ancova ini mengunnakan artikel atau jurnal yang berjumlah 20, yang terdiri dari 10 model pembelajaran Group Investigation dan 10 model pembelajaran Teams Games Tournament. Dilihat dari tabel Mean Kelas Group Investigation menghasilkan rata-rata 76,3000 sedangkan Kelas Teams Games Tournament menghasilkan rata-rata 82,2000 . Maka dari itu terdapat perbedaan yang terjadi anatar kedua model tersebut terhadap kemampuan berpikir kritis matematis pada hasil analisis data. Hasil analisis Ancova dapat dilihat pada Tabel 7 .

Tabel 7. Hasil Analisis Uji Ancova

\begin{tabular}{|c|c|c|c|c|c|c|}
\hline \multicolumn{7}{|c|}{ Dependent Variable: $\quad$ POSTTEST1 } \\
\hline Source & $\begin{array}{l}\text { Type III Sum } \\
\text { of Squares }\end{array}$ & df & Mean Square & $\mathbf{F}$ & Sig. & $\begin{array}{c}\text { Partial Eta } \\
\text { Squared }\end{array}$ \\
\hline Corrected Model & $10.157^{a}$ & 2 & 5.078 & 5.381 & .015 & .388 \\
\hline Intercept & 13.777 & 1 & 13.777 & 14.599 & .001 & .462 \\
\hline Pretest & .357 & 1 & .357 & .378 & .547 & .022 \\
\hline Kelas & 10.146 & 1 & 10.146 & 10.751 & .004 & .387 \\
\hline Error & 16.043 & 17 & .944 & & & \\
\hline Total & 1212.000 & 20 & & & & \\
\hline Corrected Total & 26.200 & 19 & & & & \\
\hline
\end{tabular}

a. R Squared $=.388$ (Adjusted $R$ Squared $=.316$ )

Dari tabel diatas untuk hasil Uji Ancova terdapat nilai Signifikasi yang dapat dilihat dari kolom kelas yaitu 0,004 . Untuk $F_{\text {hitung }}$ diperoleh dengan nilai 10,751 dan untuk $F_{\text {tabel }}$ diperoleh dengan nilai 3,59 yang dihitung melalui SPSS 24.00 for windows. Perolehan $F_{\text {tabel }}$ ini dengan menggunakan rumus df2 $=\mathrm{n}-\mathrm{k}$, dimana $\mathrm{df} 2=20-(2+1)$ hinggan menghasilkan $\mathrm{df} 2=17$ menunjukkan hasil atau nilai 3,59.

Pada uji prasyarat berikutnya ialah Uji Hipotesis yang dilakukan setelah Uji Ancova. Tujuan dari Uji Hipotesis ini mengumpulkan bukti yang berupa data-data dalam menentukan keputusan apakah hipotesis ditolak atau diterima. Berdasarkan uji-uji yang telah dilakukan, hipotesis yang akan diujikan dalam penelitian ini adalah $\mathrm{H}_{0}$ : Tidak terdapat perbedaan penerapan yang signifikan antar model pembelajaran Group Investigation dengan Teams Games Tournament terhadap keterampilan berpikir kritis pada pembelajaran matematika. Sedangkan, $\mathrm{H}_{\mathrm{a}}$ : Terdapat perbedaan penerapan yang signifikan antar model pembelajaran Group Investigation dengan Teams Games Tournament terhadap keterampilan berpikir kritis pada pembelajaran matematika. Dari hasil Uji Ancova membuktikan bahwa $F_{\text {hitung }}>F_{\text {tabel }}$ dengan nilai 10,751 $>3,59$ dan signifikasinya $0,004<0,05$ yang menunjukkan bahwa $\mathrm{H}_{0}$ ditolak dan $\mathrm{H}_{\mathrm{a}}$ diterima. Sehingga dapat disimpulkan dari data tersebut membuktikan bahwa terdapat perbedaan yang signifikan antar model pembelajaran Group Investigation dan Teams Games 
Tournament terhadap keterampilan berpikir kritis siswa sekolah dasar pada pembelajaran matematika.

Uji prasyarat yang terakhir adalah Uji Effect Size yang menggunakan teknik Cohen's $d$ melalui Uji Ancova dengan berbantuan SPSS 24.00 for Windows. Berikut adalah hasil analisis data. Uji Effect Size berdasarkan Uji Ancova dapat dilihat pada Tabel 8.

Tabel 8. Uji Effect Size berdasarkan Uji Ancova

\begin{tabular}{lrrrrrr}
\hline Dependent Variable: POSTTEST1 & & & & & \\
\hline Source & $\begin{array}{c}\text { Type III Sum } \\
\text { of Squares }\end{array}$ & Df & Mean Square & \multicolumn{1}{c}{ F } & \multicolumn{1}{c}{ Sig. } & $\begin{array}{c}\text { Partial Eta } \\
\text { Squared }\end{array}$ \\
\hline Corrected Model & $10.157^{a}$ & 2 & 5.078 & 5.381 & .015 & .388 \\
Intercept & 13.777 & 1 & 13.777 & 14.599 & .001 & .462 \\
Pretest & .357 & 1 & .357 & .378 & .547 & .022 \\
Kelas & 10.146 & 1 & 10.146 & 10.751 & .004 & .387 \\
Error & 16.043 & 17 & .944 & & & \\
\hline Total & $\mathbf{1 2 1 2 . 0 0 0}$ & $\mathbf{2 0}$ & & & & \\
\hline Corrected Total & $\mathbf{2 6 . 2 0 0}$ & $\mathbf{1 9}$ & & & & \\
\hline
\end{tabular}

Berdasarkan tabel diatas, dapat menghasilkan pengaruh yang signifikan terhadap kemampuan berpikir kritis Matematis dan hasil dari Uji Effect Size dengan tingkat sedang. . Hasil dari uji ini dapat dilihat dari data Kelas dengan Partial Eta Squared sebesar 0,297 dan nilai signifikan 0,004. Kemudian untuk data signifikasi menunjukkan bahwa model pembelajaran Group Investigation dan Teams Games Tournament memberikan pengaruh yang signifikan terhadap Kemampuan Berpikir Kritis Matematis siswa karena Signifikasi nya 0,004<0,05

\section{Pembahasan}

Berdasarkan deskripsi data hasil penelitian dengan serangkaian uji prasyarat analisis, model pembelajaran Teams Games Tournament (GI) memiliki ketarmpilan berpikir kritis dalam pembelajaran Matematika yang lebih tinggi dibandingkan dengan model pembelajaran Group Investigation. Berdasarkan analisis data menggunakan Uji Ancova mendapatkan hasil bahwa nilai posttest model pembelajaran Group Investigation yakni 76,3000 dan 82,2000 untuk model pembelajaran Teams Games Tournament. Kemudian, pada Fitung diperoleh nilai 10,751 dan untuk $F_{\text {tabel }}$ diperoleh hasil 3,59, maka $F_{\text {hitung }}>F_{\text {tabel }}$ dengan nilai 10,751 > 3,59 dan signifikasinya 0,004 <0,05. Untuk Uji Effect Size diperoleh hasil pada Partial Eta Squared yakni 0,297 dengan nilai Siginifikansi 0,004, yang menunjukkan bahwa Uji Effect Size menggunakan Uji Ancova yang menghasilkan pengaruh signifikan terhadap berpikir kritis dan hasil dari Effect Size tingkat yang sedang. Maka dapat dinyatakan dari hasil tersebut, bahwa terdapat perbedaan yang signifikan antara model Group Investigation dan model Teams Games Tournament ditinjau dari kemampuan berpikir kritis pada pembelajaran Matematika siswa Sekolah Dasar.

Hasil analisis data menggunakan Uji Ancova yang menggunakan artikel berjumlah 20 jurnal penelitian, menghasilkan rata-rata 76,3000 untuk model pembelajaran berupa Group Investigation, sedangkan rata-rata 82,2000 untuk model pembelajaran Teams Games Tournament. Pada uji Effect Size menggunakan Uji Ancova yang menghasilkan pengaruh signifikan terhadap berpikir kritis dan hasil dari Effect Size yang sedang. Dilihat dari data diatas Partial Eta Squared menunjukkan 0,297, maka dinyatakan memiliki Interprestasi yang sedang. Untuk data signifikasi menunjukkan bahwa model pembelajaran Group Investigation dan Teams Games Tournament memberikan pengaruh yang signifikan terhadap Kemampuan Berpikir Kritis Matematis siswa karena Signifikasi nya 0,004 <0,05.

Perbedaan yang Signifikan antara kedua model pembelajaran disebabkan karena perbedaan langkah-langkah dan proses penyampaian materi dengan strategi yang bervariasi. Pembelajaran dengan model kooperatif tipe Group Investigation menekankan aktivitas siswa melalui langkah-langkah, yaitu: (1) identifikasi topik serta pembagian peserta didik menjadi beberapa kelompok; (2) mempersiapkan rencana belajar; (3) melakukan investigasi; (4) menyiapkan laporan akhir; (5) menyajikan laporan akhir; (6) evaluasi. Pada model ini peserta didik dituntut untuk melakukan kerja sama dengan kelompok untuk menyelesaikan permasalahan yang diberikan oleh guru (Ardithayasa \& Yudiana, 2020; Putra et al., 2019; Wicaksono et al., 2017). Selain itu peserta didik dapat saling berbagi pengetahuan, 
beragumentasi, berpendapat, menghargai pendapat orang lain serta berusaha menggali informasi secara mandiri sedangkan guru hanya sebagai fasilitator dan motivator.

Tidak jauh berbeda dengan model pembelajaran Teams Games Tournament (TGT). Pada model pembelajaran ini dirancang untuk menguji pengetahuan akademik peserta didik saat pelaksaan kerja tim. Didalam model pembelajaran ini terdapat tournament dimana game berlangsung dengan peraturan-peraturan yang sudah dibuat. Prinsip model Teams Games Tournament menekankan pada berprosesnya setiap individu dalam kontribusinya pada kelompok dan strategi penyelesaian terkait persoalan yang dihadapi. Langkah-langkah model Teams Games Tournament sebagai berikut: 1) Presentasi di kelas, 2) pembentukan tim, 3) game, 4) turnamen sesuai dengan aturan-aturannya, 5) rekognisi tim (Cahyadi, 2016; Gunarta, 2019; Mamanda, 2018). Tujuan dari pembelajaran dalam kelompok yaitu memberikan kesempatan pada peserta didik untuk mengembangkan kemampuan memecahkan masalah secara rasional, mengembangkan sikap sosial dan semangat kerja sama, dan memiliki rasa tanggung jawab setiap individu maupun kelompok, serta mengembangkan kemampuan rasa kepemimpinan dalam kelompok.

Kemampuan berpikir kritis dapat dikembangkan atau tingkatkan dengan berbagai cara atau ide. Seperti pada mata pelajaran Matematika, dalam memecahkan masalah dalam pembelajaran Matematika menggunakan strategi, ide, serta cara dalam menyelesaikannya. Kemampuan komunikasi Matematis juga perlu dalam meningkatkan kemampuan berpikir kritis peserta didik, karena kemampuan komunikasi Matematis menjadi penting ketika diskusi antar siswa. Dimana peserta didik diharapkan mampu menyatakan, menjelaskan, mendengar, menanyakan, menggambarkan, dan berkerjasama sehingga dapat memberi pemahaman pada peserta didik yang mendalam tentang Matematika. Dalam pembelajaran Matematika, komunikasi Matematis memiliki tujuan dalam mengembangkan kemampuan peserta didiknya, yaitu kemampuan mengekspresikan ide-ide Matematis secara lisan, tertulis, dapat mendemonstrasikan serta menjelaskan atau menggambarkan secara visual, kemampuan dalam memahami, menginterprentasikan dan evaluasi ide-ide Matematika baik secara lisan maupun dalam bentuk lainnya, dan kemampuan menggunakan notasi-notasi Matematika, istilah-istilah, dan struktur-strukturnya untuk menyajikan sebuah ide (Alawiah et al., 2018; Dina Indriyani et al., 2019; Sidiq \& Prasetyo, 2020).

Perbedaan cara pembelajaran antara pembelajaran dengan model kooperatif tipe Group Investigation (GI) dengan model pembelajaran Teams Games Tournament (TGT) yang memberikan dampak yang berbeda pula terhadap keterampilan berpikir kritis peserta didik dalam pembelajaran Matematika. Penggunaan model pembelajaran Group Investigation dan Teams Games Tournament dalam pembelajaran memberi peluang bagi peserta didik untuk tahu manfaat dari materi yang dipelajari bagi kehidupannya, aktif dan kreatif dalam pembelajaran, mandiri dalam menemukan konsep-konsep yang dipelajari, mampu memecahkan masalah-masalah yang berkaitan dengan konsep pembelajaran, mampu berkerjasama tim, dan dapat mengungkapkan pendapat (Ardithayasa \& Yudiana, 2020; Putra et al., 2019; Wicaksono et al., 2017). Peserta didik diberikan kesempatan untuk mengembangkan dan meningkatkan kemampuan berpikir kritis Matematis dan daya temu terhadap masalahmasalah yang muncul sendiri maupun diberikan oleh guru.

Seluruh data yang diperoleh melalui berbagai uji statistik meliputi; (1) Uji Distribusi Kinerja Model Pembelajaram; (2) Uji Normalitas; (3) Uji Homogenitas; (4) Uji Linearitas; (5) Uji Ancova; (6) Uji Hipotesis dan terakhir; (7) Effect Size. Secara umum hasil perolehan mean antara model Group Investigation (GI) dan Teams Games Tournament (TGT) memiliki perbedaan selisih. Penggunaan model Teams Games Tournament (TGT) secara peningkatan presentase kemampuan berpikir kritis Matematika lebih tinggi di bandingkan dengan model Group Investigation (GI). Berdasarkan pemaparan hasil penelitian dan pembahasan diatas, dapat dinyatakan bahwa Keefektifan model pembelajaran Group Investigation (GI) dan Teams Games Tournament (TGT) memiliki kualitas yang sama dalam pengaruh terhadap Keterampilan Berpikir Kritis Matematika peserta didik.

Penelitian ini didukung oleh beberapa penelitia sebelumnya yang relevan dengan penelitian ini seperti: (1) penelitian yang dilaksanakan oleh (Wicaksono et al., 2017), yang memperoleh hasil bahwa model pembelajaran group investigation dan think pair share terbukti berpengaruh terhadap kemampuan berpikir kritis siswa; (2) penelitian yang dilaksanakan oleh (Cahyadi, 2016), yang memperoleh hasil bahwa penerapan model TGT terbukti berpengaruh terhadap meningkatkan penguasaan kompetensi pengetahuan IPA siswa; (3) penelitian yang dilaksanakan oleh (Miatun \& Khusna, 2020), yang memperoleh hasil bahwa peningkatan kemampuan berpikir kritis matematis siswa dipengaruhi berdasarkan disposisi matematis 


\section{Simpulan dan Saran}

Berdasarkan hasil penelitian dan pembahasan di atas, maka simpulan penelitian ini adalah keefektifan model pembelajaran Group Investigation dan Teams Games Tournament terhadap keterampilan berpikir kritis dalam pembelajaran Matematis pada peserta didik memiliki interpretasi tingkat sedang serta dapat meningkatkan kemampuan keterampilan berpikir krittis Matematika siswa sekolah dasar. Pernyataan tersebut bisa dilihat berdasarkan hasil dari Uji Ancova terhadap model pembelajaran Group Investigation menghasilkan rata-rata 763,000. Sedangkan untuk model pembelajaran Teams Games Tournament menghasilkan rata-rata 822,000. Kemudian untuk nilai Signifikasi pada Uji Ancova yaitu 0,004. Untuk F hitung diperoleh dengan nilai 10,751 dan untuk $\mathrm{F}_{\text {tabel }}$ diperoleh dengan nilai 3,59 yang dihitung melalui SPSS 24.00 for windows. Dari hasil Uji Ancova membuktikan bahwa Fhitung $>F_{\text {tabel }}$ dengan nilai 10,751 $>3,59$ dan signifikasinya $0,004<0,05$ yang menunjukkan bahwa $\mathrm{H}_{0}$ ditolak dan $\mathrm{H}_{a}$ diterima. Hasil dari Uji Effect Size menggunakan Uji Ancova memiliki keefektifan yang signifikan terhadap keterampilan berpikir kritis dan data memiliki Interprestasi tingkat yang sedang, maka dapat dilihat dari data Partial Eta Squared yang menunjukkan hasil 0,297. Sehingga dapat disimpulkan dari data tersebut membuktikan bahwa terdapat perbedaan keefektifan yang signifikan antar model pembelajaran Group Investigation dan Teams Games Tournament terhadap keterampilan berpikir kritis siswa sekolah dasar pada pembelajaran Matematika.

Saran yang dapat disampaikan berdasarkan penelitian yang telah dilakukan adalah guru dapat mengembangkan atau meningkatkan kreativitas dari berbagai model pembelajaran untuk model yang lebih bervariatif lagi. Model pembelajaran akan lebih berpengaruh jika didalam pelaksanaannya siswa lebih aktif, kreatif, inovatif, dan efektif dalam memecahkan suatu masalah.

\section{Daftar Pustaka}

Alawiah, L. T., Rahmatina, D., \& Febrian, F. (2018). Meningkatkan Kemampuan Berpikir Kritis melalui Alat Peraga Pilogma pada Materi Logika Matematika. Jurnal Gantang, 3(1), 5562. https://doi.org/10.31629/jg.v3i1.384

Aprilia, L. A. (2018). Meningkatkan Hasil Belajar Ppkn Melalui Model Pembelajaran Numbered Heads Together (Nht) Berbasis Kurikulum 2013. Wacana Akademika: Majalah IImiah Kependidikan, 2(1). https://doi.org/10.30738/wa.v2i1.2530

Ardianingsih, F., Mahmudah, S., \& Rianto, E. (2017). Peran Guru Dalam Implementasi Kurikulum 2013 Pendidikan Khusus Pada Sekolah Luar Biasa Di Sidoarjo. Jurnal Pendidikan, 2(1), 14-20. https://doi.org/10.26740/jp.v2n1.p21-30

Ardithayasa, I. W., \& Yudiana, K. (2020). Model Pembelajaran Group Investigation (GI) Berbasis Tri Hita Karana Terhadap Hasil Belajar IPA. Jurnal Ilmiah Sekolah Dasar, 4(2), 163-173. https://doi.org/10.238872Fjisd.v4i2.25105

Awalia, I., Pamungkas, A. S., \& Alamsyah, T. P. (2019). Pengembangan Media Pembelajaran Animasi Powtoon pada Mata Pelajaran Matematika di Kelas IV SD. Kreano, Jurnal Matematika Kreatif-Inovatif, 10(1), 49-56. https://doi.org/10.15294/kreano.v10i1.18534

Cahyadi, M. I. W. (2016). Penerapan Model TGT Meningkatkan Penguasaan Kompetensi Pengetahuan IPA Siswa Kelas VB SD Negeri 8 Pemecutan. MIMBAR PGSD Undiksha, 4(1), 1-10. https://doi.org/10.23887/jjpgsd.v4i1.7521

Dewi, A. C., Hapidin, H., \& Akbar, Z. (2019). Pengaruh Model Pembelajaran dan Kemampuan Berpikir Kritis terhadap Pemahaman Sains Fisik. Jurnal Obsesi: Jurnal Pendidikan Anak Usia Dini, 3(1), 18-29. https://doi.org/10.31004/obsesi.v3i1.136

Gazali, R. Y., \& Atsnan, M. F. (2017). Peningkatan Motivasi Dan Minat Belajar Matematika Siswa Melalui Pendekatan Kontekstual Dalam Pembelajaran Matematika Yang Bermakna. Pythagoras: Jurnal Pendidikan Matematika, 12(2), 123-134. https://doi.org/10.21831/pg.v12i2.15987

Gunarta, I. G. (2019). Pengaruh Model Pembelajaran TGT Berbantuan Media Question Card Terhadap Hasil Belajar IPA. Jurnal Pedagogi Dan Pembelajaran, 1(2), 112. 
https://doi.org/10.23887/jp2.v1i2.19338

Hasnan, S. M., Rusdinal, R., \& Fitria, Y. (2020). Pengaruh Penggunaan Model Discovery Learning Dan Motivasi Terhadap Kemampuan Berpikir Kritis Peserta Didik Sekolah Dasar. Jurnal Basicedu, 4(2), 239-249. https://doi.org/10.31004/basicedu.v4i2.318

Herzon, H. H., Budijanto, \& Utomo, D. H. (2018). Pengaruh Problem-Based Learning (PBL) terhadap Keterampilan Berpikir Kritis. Jurnal Pendidikan: Teori, Penelitian, Dan Pengembangan, 3(1), 42-46. http://journal.um.ac.id/index.php/jptpp/

Ilham, M., \& Hardiyanti, W. E. (2020). Pengembangan Perangkat Pembelajaran Ips Dengan Metode Saintifik Untuk Meningkatkan Kemampuan Berpikir Kritis Siswa Materi Globalisasi Di Sekolah Dasar. Jurnal IImiah Pendidikan Dasar, 7(1), 12-29. https://doi.org/10.30659/pendas.7.1.12-29

Indriani, A. (2015). Penerapan Pembelajaran Tematik Kurikulum 2013 oleh Guru SD/MI di Desa Klepek Kecamatan Sukosewu Kabupaten Bojonegoro Semester Gasal Tahun Ajaran 2014/2015. Jurnal VARIDIKA, 27(1), 43-49. https://doi.org/10.23917/varidika.v27i1.738

Indriyani, D., Mawardi, M., \& Wardani, K. W. (2019). Peningkatan Keterampilan Berpikir Kritis Melalui Model Inkuiri Berbantuan Media Konkret Pada Siswa Kelas 5 Sd Negeri Mangunsari 05 Tahun Pelajaran 2018/2019. Jurnal Basicedu, 3(1), 27-32. https://doi.org/10.31004/basicedu.v3i1.67

Indriyani, Dina, Mawardi, M., \& Wardani, K. W. (2019). Peningkatan Keterampilan Berpikir Kritis Melalui Model Inkuiri Berbantuan Media Konkret Pada Siswa Kelas 5 Sd Negeri Mangunsari 05 Tahun Pelajaran 2018/2019. Jurnal Basicedu, 3(1), 27-32. https://doi.org/10.31004/basicedu.v3i1.67

Irawan, E. (2016). Implementasi Penanaman Karakter Melalui Matematika Pada Kurikulum 2013. Ibriez: Jurnal Kependidikan Dasar Islam Berbasis Sains, 1(1), 1-18. https://doi.org/10.21154/ibriez.v1i1.4

Kristiyanto, D. (2020). Peningkatan Kemampuan Berpikir Kritis dan Hasil Belajar Matematika dengan Model Project Based Learning (PJBL). Mimbar IImu, 25(1), 1-10. https://doi.org/10.23887/mi.v25i1.24468

Machali, I. (2014). Kebijakan Perubahan Kurikulum 2013 dalam Menyongsong Indonesia Emas Tahun 2045. Jurnal Pendidikan Islam, 3(1), 71. https://doi.org/10.14421/jpi.2014.31.7194

Mamanda, S. (2018). Penerapan Model Pembelajaran Kooperatif Tipe Teams Game Tournaments (TGT) untuk Meningkatkan Hasil Belajar IImu Pengetahuan Sosial. Jurnal Penelitian Dan Pengembangan Pendidikan, 2(3), 256. https://doi.org/10.23887/jppp.v2i3.16283

Marudut, M. R. H., Bachtiar, I. G., Kadir, \& lasha, V. (2020). Peningkatan Kemampuan Berpikir Kritis Dalam Pembelajaran Ipa Melalui Pendekatan Keterampilan Proses. Jurnal Basicedu, 4(3), 577-585. https://doi.org/10.31004/basicedu.v4i3.401

Miatun, A., \& Khusna, H. (2020). Kemampuan Berpikir Kritis Matematis Berdasarkan Disposisi Matematis. AKSIOMA: Jurnal Program Studi Pendidikan Matematika, 9(2), 269-278. https://doi.org/10.24127/ajpm.v9i2.2703

Putra, P. G. N., Margunayasa, I. G., \& Wibawa, I. M. C. (2019). Pengaruh Model Pembelajaran Kooperatif Tipe Group Investigation (GI) Berbasis Lesson Study Terhadap Penguasaan Konsep IPA. Jurnal Pedagogi Dan Pembelajaran, 1(2), 84. https://doi.org/10.23887/jp2.v1i2.19329

Putri, A., Sumardani, D., Rahayu, W., \& Hajizah, M. N. (2020). Kemampuan Berpikir Kritis Matematis Menggunakan Model Generative Learning Dan Connecting, Organizing, Reflecting, Extending (CORE). Aksioma: Jurnal Program Studi Pendidikan Matematika, 9(1), 108-117. https://doi.org/10.24127/ajpm.v9i1.2617

Rizta, A., \& Antari, L. (2018). Pengembangan Tes Kemampuan Komunikasi Matematis Pada Materi Sistem Persamaan Linear Untuk Mahasiswa Calon Guru Matematika. AKSIOMA: Jurnal Program Studi Pendidikan Matematika, 7(2), 291-299. 
https://doi.org/10.24127/ajpm.v7i2.1525

Sidiq, M. A., \& Prasetyo, T. (2020). Efektivitas Model Pembelajaran Problem Solving dan Discovery Learning Terhadap Kemampuan Berpikir Kritis Siswa Sekolah Dasar. Jurnal Basicedu, 4(2), 361-370. https://doi.org/10.31004/basicedu.v4i2.358

Sugiyanto, S., Kartowagiran, B., \& Jailani, J. (2015). Pengembangan Model Evaluasi Proses Pembelajaran Matematika Di SMP Berdasarkan Kurikulum 2013. Jurnal Penelitian Dan Evaluasi Pendidikan, 19(1), 82-95. https://doi.org/10.21831/pep.v19i1.4558

Suriasa. (2018). Penerapan Model Pembelajaran Problem Posing Menggunakan LKS Berbasis Scientific Aproach Untuk Meningkatkan Keterampilan Berpikir Kritis Siswa. Berkala IImiah Pendidikan Fisika, 6(2), 190-204. https://doi.org/10.20527/bipf.v6i2.4853

Syarifah, \& Sumardi, Y. (2015). Pengembangan Model Pembelajaran Malcolm'S Modeling Untuk Meningkatkan Keterampilan Berpikir Kritis Dan Motivasi Belajar Siswa. Jurnal Inovasi Pendidikan IPA, 1(2), 237-247. https://doi.org/10.21831/jipi.v1i2.7510

Trimawati, K., Kirana, T., \& Raharjo, R. (2020). Pengembangan Instrumen Penilaian Ipa Terpadu Dalam Pembelajaran Model Project Based Learning (PjBL) Untuk Meningkatkan Kemampuan Berpikir Kritis Dan Kreatif Siswa SMP. Quantum: Jurnal Inovasi Pendidikan Sains, 11(1), 36. https://doi.org/10.20527/quantum.v11i1.7606

Wicaksono, B., Sagita, L., \& Nugroho, W. (2017). Model Pembelajaran Group Investigation (Gi) Dan Think Pair Share (Tps) Terhadap Kemampuan Berpikir Kritis. Aksioma, 8(2), 1. https://doi.org/10.26877/aks.v8i2.1876

Yanwar, A., \& Fadila, A. (2019). Analisis Kemampuan Berpikir Kritis Matematis: Dampak Pendekatan Saintifik ditinjau dari Kemandirian Belajar. Desimal: Jurnal Matematika, 2(1), 9-22. https://doi.org/10.24042/djm.v2i1.3204 